\title{
Coupled enzymatic hydrolysis and ethanol fermentation: ionic liquid pretreatment for enhanced yields
}

\author{
Venkata Prabhakar Soudham ${ }^{1,2 *}$, Dilip Govind Raut ${ }^{1}$, Ikenna Anugwom', Tomas Brandberg ${ }^{2}$, Christer Larsson ${ }^{2}$ \\ and Jyri-Pekka Mikkola ${ }^{1,3^{*}}$
}

\begin{abstract}
Background: Pretreatment is a vital step upon biochemical conversion of lignocellulose materials into biofuels. An acid catalyzed thermochemical treatment is the most commonly employed method for this purpose. Alternatively, ionic liquids (ILS), a class of neoteric solvents, provide unique opportunities as solvents for the pretreatment of a wide range of lignocellulose materials. In the present study, four ionic liquid solvents (ILs), two switchable ILs (SILs) DBUMEA-SO $\mathrm{S}_{2}$ and DBU-MEA-CO ${ }_{2}$, as well as two 'classical' ILs [Amim] $\left[\mathrm{HCO}_{2}\right]$ and [AMMorp][OAc], were applied in the pretreatment of five different lignocellulosic materials: Spruce (Picea abies) wood, Pine (Pinus sylvestris) stem wood, Birch (Betula pendula) wood, Reed canary grass (RCG, Phalaris arundinacea), and Pine bark. Pure cellulosic substrate, Avicel, was also included in the study. The investigations were carried out in comparison to acid pretreatments. The efficiency of different pretreatments was then evaluated in terms of sugar release and ethanol fermentation.
\end{abstract}

Results: Excellent glucan-to-glucose conversion levels (between 75 and $97 \%$, depending on the biomass and pretreatment process applied) were obtained after the enzymatic hydrolysis of IL-treated substrates. This corresponded between 13 and $77 \%$ for the combined acid treatment and enzymatic hydrolysis. With the exception of $77 \%$ for pine bark, the glucan conversions for the non-treated lignocelluloses were much lower. Upon enzymatic hydrolysis of ILtreated lignocelluloses, a maximum of $92 \%$ hemicelluloses were also released. As expected, the ethanol production upon fermentation of hydrolysates reflected their sugar concentrations, respectively.

Conclusions: Utilization of various ILs as pretreatment solvents for different lignocelluloses was explored. SIL DBUMEA-SO $\mathrm{S}_{2}$ was found to be superior solvent for the pretreatment of lignocelluloses, especially in case of softwood substrates (i.e., spruce and pine). In case of birch and RCG, the hydrolysis efficiency of the SIL DBU-MEA-CO ${ }_{2}$ was similar or even better than that of DBU-MEA-SO . Further, the IL [AMMorp][OAc] was found as comparably efficient as DBU-MEA- $\mathrm{CO}_{2}$. Pine bark was highly amorphous and none of the pretreatments applied resulted in clear benefits to improve the product yields.

Keywords: Lignocellulose, (Switchable) lonic liquids, Pretreatment, Hydrolysis, Fermentation, Ethanol, Bio-fuels

\section{Background}

Second-generation biorefineries based on the exploitation of lignocellulose as the main carbon source, have

\footnotetext{
*Correspondence: venkata.soudham@gmail.com; jyri-pekka.mikkola@ umu.se

${ }^{1}$ Department of Chemistry, Technical Chemistry and Sustainable Chemical Technology, Chemical-Biological Centre, Umeå University, 901 87 Umeå, Sweden

Full list of author information is available at the end of the article
}

the potential to produce a variety of products, including bio-fuels, value-added chemicals, materials, heat and electricity [1-3]. However, laboratory scale experiments often report limited product yields due to the complex structure and high crystallinity of the feedstock. As known, lignocelluloses are mainly composed of cellulose, hemicelluloses, and lignin. Cellulose and hemicelluloses are carbohydrate polysaccharides while lignin is a complex aromatic polymer [4]. In combination, these three 
main components form a complex structure of vegetal biomass. In a typical biomass conversion process, the raw material is pre-treated to improve the accessibility of polysaccharides for their further conversion into monosaccharides. This is typically performed via processing of biomass in environmentally harmful chemicals, such as sulfuric acid that facilitates the hydrolysis and extraction of sugars leaving most of the lignin in the solid residue. Alternatively, lignin can be removed by the use of alkaline solutions or organic solvents, leaving solids rich in sugar polysaccharides. Already, a number of pretreatment methods based on the use of different solvents, e.g., acids, alkali, organic solvents and/or other techniques like steam explosion, ammonia fiber explosion, etc. have been introduced for lignocellulose disruption and are well reviewed [5-11]. The lignin-rich residues obtained from an acid pretreatment can be used as low-value boiler fuel to produce heat and electricity [12]. Moreover, lignin can also be considered as a valuable source of carbon and if selectively removed and recovered it can be used to produce high value derivatives $([5,6,13])$. After completed pretreatment, enzymes can be used to further degrade and hydrolyze the polysaccharides into monosaccharides which can then be used to produce various products such as alcoholic fuels (e.g., ethanol, butanol) via fermentation [14-17].

If the applied pretreatment is inefficient, the downstream hydrolysis and fermentation are likely to give low product yields [12]. Pretreatment is, therefore, a very important step in lignocellulose conversion processes. Thus, the refinement of lignocellulose pretreatment technologies is necessary to further facilitate enzymatic degradation of polysaccharides, improve product yields, and move closer to an economically viable lignocellulose biorefinery.

Ionic liquids (ILs), salts composed of organic cations and either organic or inorganic anions [18]; these neoteric solvents have lately attracted significant attention due to their ability to dissolve a wide range of organic and inorganic compounds, including lignocellulosic materials $[19,20]$. Because of their unique physicochemical properties and potential for associated environmental benefits, ILs are considered to be of interest as potential alternatives to the traditional lignocellulose pretreatment solvents and a variety of ILs have been applied in fractionation and dissolution different lignocelluloses [6, 8, 21-23]. Nevertheless, many ILs are expensive [24] and biomass treatment was in many cases performed at rather low temperatures and with retention times of up to several days [6]. Thus, design of low-cost ILs [24] that efficiently work at high temperatures and with a short processing time is of interest. Among the investigated ones, the use of inexpensive acidic ILs that can be produced on bulk scale is potentially a sustainable approach of lignocellulosic biomass conversion without addition of catalyst $[25,26]$.

The new acidic switchable ILs (SILs) DBU-MEA$\mathrm{SO}_{2}$ (DBU: 1,8-diazabicyclo[5.4.0] undec-7-ene; MEA: monoethanolamine) and DBU-MEA- $\mathrm{CO}_{2}$ have been reported to be efficient for optimal fractionation and selective removal of almost all lignin from the Nordic woody biomass $[27,28]$. In addition, among the more commonly applied cellulose-dissolving ILs (CILs) such as $\left[\mathrm{C}_{2} \mathrm{mim}\right][\mathrm{OAc}][29-32]$ and $\left[\mathrm{C}_{4} \mathrm{mim}\right] \mathrm{Cl}[29,30]$, [Amim] $\left[\mathrm{HCO}_{2}\right]$ and [AMMorp][OAc] were proven to be efficient for the dissolution of lignocellulose substrates [33, 34]. Hence, the present study focuses on investigation of above mentioned four (S)ILs in pretreatment, at high temperatures and with a short processing time.

\section{Results}

Chemical composition of different lignocelluloses

The composition of structural carbohydrates, lignin and extractives of different lignocelluloses used in this study are presented in Table 1 . The values in Table 1 are comparable to those reported in the literature [7, 35-37]. Softwood substrates, i.e., spruce and pine, are rich in glucomannans, while both birch (a hard wood substrate) and reed canary grass are rich in glucoxylanes (Table 1). On the contrary, pine bark contains high amounts of arabinoglucans (Table 1). As expected, lignin content of softwood substrates was higher than that of hardwood and reed canary grass. Nevertheless, pine bark displayed the highest lignin content of $40.3 \%$ (dry wt). Pine bark was also exclusively rich in extractives [19.4\% (dry wt)] while the extractives content of other substrates was maximally $4 \%$ (dry wt) (Table 1).

\section{Enzymatic hydrolysis of (S)IL-treated and non-treated Avicel cellulose}

In Initial experiments, a model crystalline cellulose Avicel was treated with various IL solvents at a severity factor (SF) of 2.5 and subsequently subjected to enzymatic hydrolysis. As control, Avicel was hydrolyzed without any pretreatment. After $48 \mathrm{~h}$ of enzymatic hydrolysis, the glucose yields (g glucose released/g maximum available glucose) were $0.68,0.69,0.81,0.70$, and 0.80 for the non-treated and the samples treated with DBU-MEA$\mathrm{SO}_{2}, \mathrm{DBU}-\mathrm{MEA}-\mathrm{CO}_{2}$, [Amim] $\left[\mathrm{HCO}_{2}\right]$ and [AMMorp] [OAc], respectively. Compared to non-treated material, the glucose production rates (GPRs, calculated from the first 4 h of hydrolysis) were 44, 10 and $42 \%$ higher for the Avicel treated with DBU-MEA-CO , $[$ Amim $]\left[\mathrm{HCO}_{2}\right]$ and [AMMorp][OAc], respectively (Fig. 1). Hence, use of $\mathrm{DBU}-\mathrm{MEA}-\mathrm{CO}_{2}$ and [AMMorp][OAc] resulted in most successful treatments for Avicel cellulose, whereas 
Table 1 Relative masses of polysaccharides, lignin, and extractives of different lignocelluloses

\begin{tabular}{|c|c|c|c|c|c|c|c|}
\hline \multirow[t]{2}{*}{ Lignocellulose substrate } & \multicolumn{7}{|c|}{ Component (dry wt\%) } \\
\hline & Arabinan & Galactan & Glucan & Xylan & Mannan & Lignin $^{a}$ & Extractives $^{b}$ \\
\hline Spruce wood & $\begin{array}{l}1.9 \\
( \pm 0.1)\end{array}$ & $\begin{array}{l}1.6 \\
( \pm 0.1)\end{array}$ & $\begin{array}{l}41.0 \\
( \pm 1.1)\end{array}$ & $\begin{array}{l}4.7 \\
( \pm 0.3)\end{array}$ & $\begin{array}{l}9.7 \\
( \pm 0.3)\end{array}$ & $\begin{array}{l}28.3 \\
( \pm 0.1)\end{array}$ & $\begin{array}{l}2.8 \\
( \pm 0.5)\end{array}$ \\
\hline Pine stem wood & $\begin{array}{l}2.0 \\
( \pm 0.1)\end{array}$ & $\begin{array}{l}2.7 \\
( \pm 0.2)\end{array}$ & $\begin{array}{l}40.3 \\
( \pm 0.7)\end{array}$ & $\begin{array}{l}5.2 \\
( \pm 0.4)\end{array}$ & $\begin{array}{l}9.2 \\
( \pm 0.4)\end{array}$ & $\begin{array}{l}27.5 \\
( \pm 0.5)\end{array}$ & $\begin{array}{l}4.0 \\
( \pm 0.4)\end{array}$ \\
\hline Birch wood & $\begin{array}{l}0.9 \\
( \pm 0.1)\end{array}$ & $\begin{array}{l}0.6 \\
( \pm 0.1)\end{array}$ & $\begin{array}{l}38.0 \\
( \pm 0.6)\end{array}$ & $\begin{array}{l}17.5 \\
( \pm 0.6)\end{array}$ & $\begin{array}{l}1.6 \\
( \pm 0.2)\end{array}$ & $\begin{array}{l}23.7 \\
( \pm 0.6)\end{array}$ & $\begin{array}{l}3.3 \\
( \pm 0.1)\end{array}$ \\
\hline Reed canary grass & $\begin{array}{l}2.6 \\
(<0.1)\end{array}$ & $\begin{array}{l}1.2 \\
( \pm 0.1)\end{array}$ & $\begin{array}{l}36.8 \\
( \pm 1.3)\end{array}$ & $\begin{array}{l}16.4 \\
( \pm 0.5)\end{array}$ & $\begin{array}{l}0.8 \\
(<0.1)\end{array}$ & $\begin{array}{l}23.1 \\
( \pm 0.9)\end{array}$ & $\begin{array}{l}3.5 \\
( \pm 0.7)\end{array}$ \\
\hline Pine bark & $\begin{array}{l}12.2 \\
( \pm 0.1)\end{array}$ & $\begin{array}{l}3.0 \\
( \pm 0.1)\end{array}$ & $\begin{array}{l}16.7 \\
(<0.1)\end{array}$ & $\begin{array}{l}1.7 \\
( \pm 0.2)\end{array}$ & $\begin{array}{l}1.5 \\
( \pm 0.2)\end{array}$ & $\begin{array}{l}40.3 \\
( \pm 2.2)\end{array}$ & $\begin{array}{l}19.4 \\
( \pm 2.1)\end{array}$ \\
\hline
\end{tabular}

Data shown as percentage in dry weight; values represent the mean of three replicates; standard error is given in parentheses

a Total lignin, i.e., Klason lignin plus acid soluble lignin

b Ethanol extractives

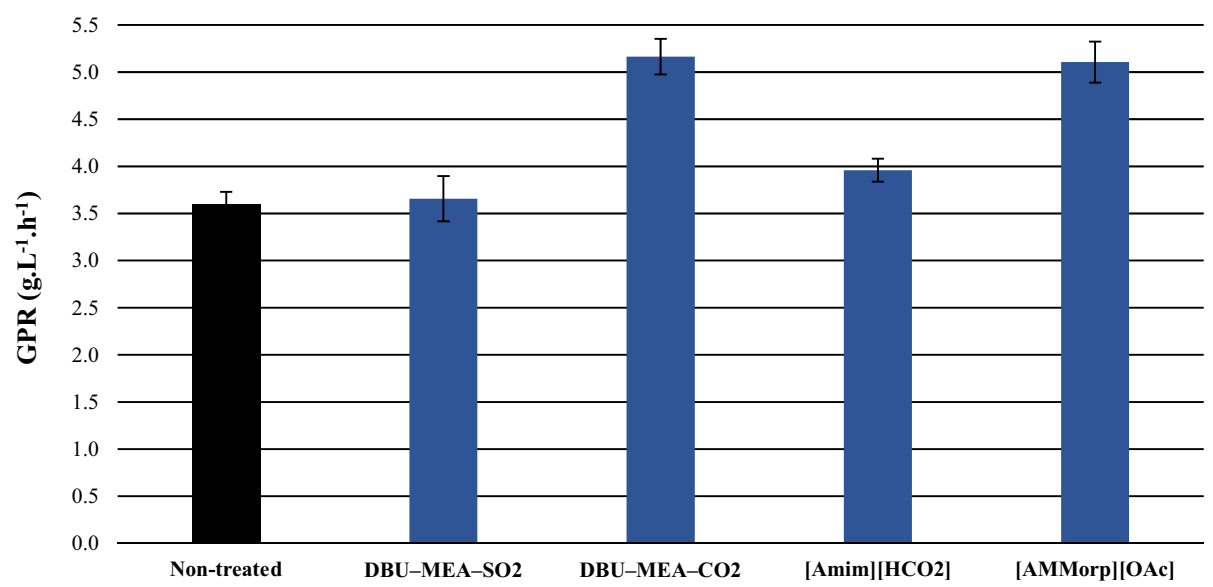

Fig. 1 Glucose production rates (GPRs) during 4 h enzymatic hydrolysis of Avicel cellulose. Hydrolysis experiments were performed with either non-treated or (S)IL (SF 2.5)-treated Avicel cellulose

treatment with DBU-MEA-SO $\mathrm{S}_{2}$ did not result in any improvement in subsequent enzymatic hydrolysis.

Enzymatic hydrolysis of non-treated, acid pre-hydrolyzed, and IL-treated lignocellulose substrates

\section{Soft wood substrates}

In case of softwood substrates such as spruce wood and pine stem wood, an acid pre-hydrolysis was not beneficial for the subsequent enzymatic degradation (Figs. 2a, b, 4a, b). The GPRs $\left(\sim 0.6 \mathrm{~g} \mathrm{~L}^{-1} \mathrm{~h}^{-1}\right)$ and the glucose yields (11$13 \%)$ were similar for the enzymatic hydrolysis of nontreated and the solids of acid pre-hydrolysis (S-APH).

Compared with both non-treated and acid pre-hydrolyzed, softwood substrates originating from IL treatments were readily degraded by enzymes-hydrolysis rates were significantly enhanced and high sugar conversions were observed (Figs. 2a, b, 4a, b). Upon enzymatic hydrolysis of (S)IL-treated substrates, the GPRs and glucose yields were enhanced to a maximum of 1.1-2.7 $\mathrm{g} \mathrm{L}^{-1} \mathrm{~h}^{-1}$ and 28-75\% for spruce wood, and 1.3-3.6 $\mathrm{g} \mathrm{L}^{-1} \mathrm{~h}^{-1}$ and 39-93\% for pine stem wood. In addition, the hemicellulose recovery 61 and $71 \%$ from the enzymatic hydrolysis of (S)IL spruce and pine, respectively, were slightly higher than that of 57 and $65 \%$ recovered from the combined acid pre-hydrolysis and enzymatic hydrolysis.

DBU-MEA- $\mathrm{SO}_{2}$ was the best solvent for the pretreatment of softwood substrates, followed by DBU-MEA$\mathrm{CO}_{2}$ and [AMMorp][OAc]. It should be noted, that IL [AMMorp][OAc] appeared to be in the same magnitude of order as DBU-MEA- $\mathrm{CO}_{2}$.

\section{Hardwood substrate}

Acid pre-hydrolysis of hard wood such as birch was beneficial and improved the subsequent enzymatic hydrolysis 

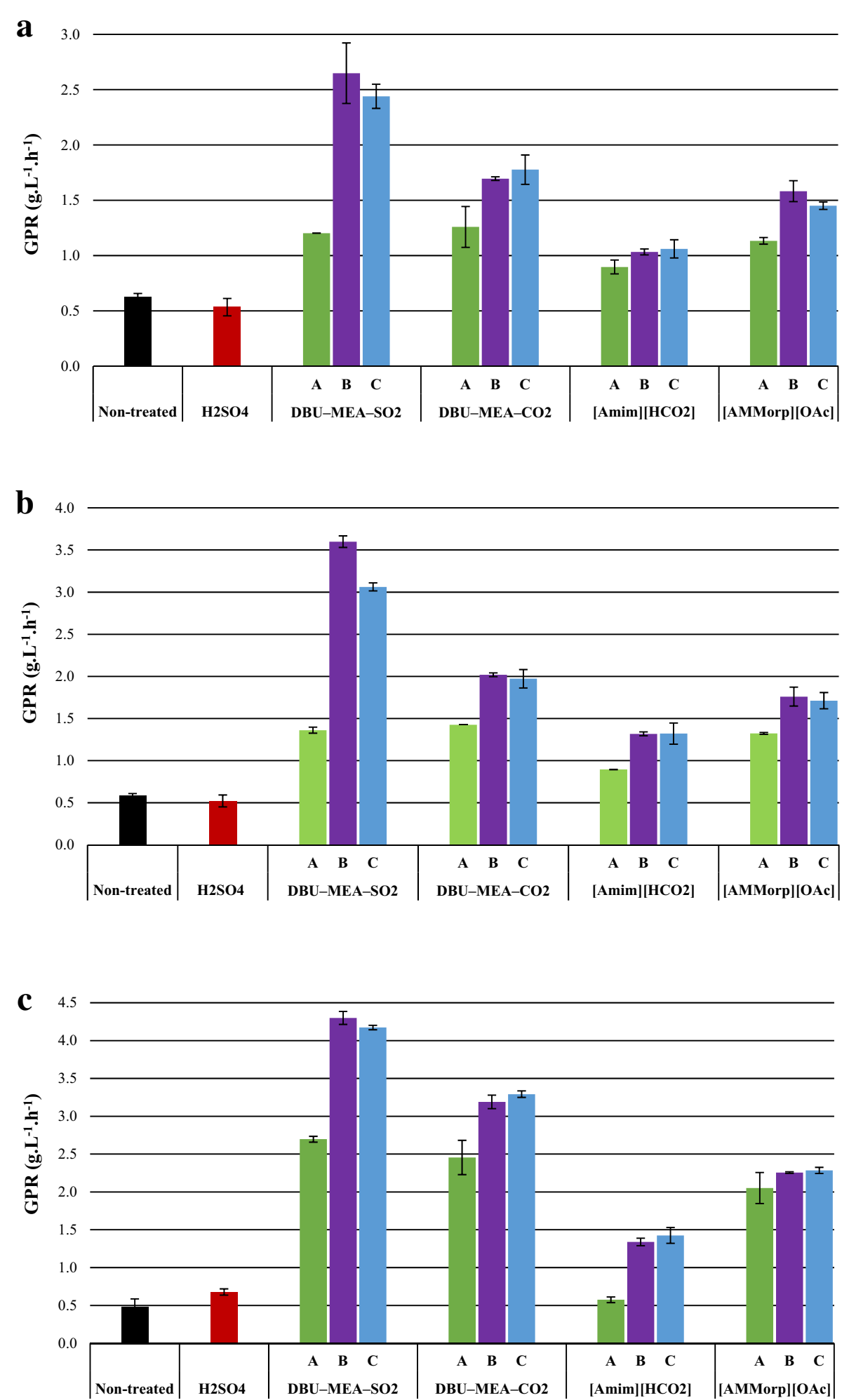

Fig. 2 Glucose production rates (GPRs) during 4-h enzymatic hydrolysis of lignocellulose substrates. a Spruce wood; b Pine stem wood; c Birch wood. Enzymatic hydrolysis experiments were performed with either non-treated or $\mathrm{H}_{2} \mathrm{SO}_{4}$-treated (SF 4.1), or (S)IL-treated lignocelluloses. (S)IL treatments were performed at (A) SF 2.5 (B) SF 3.7 and (C) SF 4.1 
(Figs. 2c, 4c). The GPR increased from 0.5 to $0.7 \mathrm{~g} \mathrm{~L}^{-1} \mathrm{~h}^{-1}$ and the glucose yields from 10 to $20 \%$ in S-APH samples compared to non-treated birch wood.

Similar to softwoods, enzymatic hydrolysis of (S)ILtreated birch wood was highly efficient. A maximum GPR of 1.4-4.3 $\mathrm{g} \mathrm{L}^{-1} \mathrm{~h}^{-1}$ and glucose yields of $47-96 \%$ were obtained from the enzymatic hydrolysis of (S)IL-treated birch wood (Figs. 2c, 4c). In fact, the hemicellulose recovery $\max 92 \%$ from the enzymatic hydrolysis of (S)IL-treated birch wood was comparably higher than the $56 \%$ recovered from the combined acid pre-hydrolysis and enzymatic hydrolysis of birch wood. The tendency of (S)ILs efficiency for birch wood was similar to that of softwood substrates, but the sugar yields (glucose 95-96\%, overall 93-94 \%) were similar irrespective of whether they were DBUMEA-SO ${ }_{2}$ or DBU-MEA-CO $($ Fig. 4c). However, the GPR maximum $3.3 \mathrm{~g} \mathrm{~L}^{-1} \mathrm{~h}^{-1}$ for the DBU-MEA-CO ${ }_{2}$-treated birch wood was lower than the $4.3 \mathrm{~g} \mathrm{~L}^{-1} \mathrm{~h}^{-1}$ of DBU$\mathrm{MEA}-\mathrm{SO}_{2}$-treated substrate. The glucose yields for the [AMMorp] [OAc]-treated birch wood also reached as high as $91 \%$, but the maximum GPR was only $2.3 \mathrm{~g} \mathrm{~L}^{-1} \mathrm{~h}^{-1}$.

\section{Agricultural residues}

Surprisingly, unlike any investigated lignocellulose substrates, no sugars were released from the enzymatic hydrolysis of non-treated reed canary grass (Figs. 3a, 5a). However, acid pre-hydrolysis of reed canary grass significantly improved its subsequent enzymatic degradation. Enzymatic hydrolysis of S-APH of reed canary grass resulted in $47 \%$ glucose yield with a GPR of $1.8 \mathrm{~g} \mathrm{~L}^{-1} \mathrm{~h}^{-1}$.

The hydrolysis efficiency of reed canary grass was further enhanced by (S)IL treatments. Upon enzymatic hydrolysis of (S)IL-treated reed canary grass, a maximum GPRs of 2.1-4.6 $\mathrm{g} \mathrm{L}^{-1} \mathrm{~h}^{-1}$ and glucose yields of 55-97 \% were obtained. For reed canary grass, both SILs DBU-MEA- $\mathrm{SO}_{2}$ and DBU-MEA-CO ${ }_{2}$ were similarly efficient in terms of GPRs and yields. Even though, IL [AMMorp][OAc] was as efficient as SILs still the GPRs for [AMMorp][OAc] treated reed canary grass were slightly lower than for the S-ILs-treated substrates. However, at less sever treatment conditions (i.e. SF 2.5), DBU-MEA$\mathrm{CO}_{2}$ was better solvent than other (S)ILs, resulting a $4.3 \mathrm{~g} \mathrm{~L}^{-1} \mathrm{~h}^{-1}$ GPR and $94 \%$ glucose yield. Nonetheless, the hemicellulose recovery from the (S)ILs-treated reed canary grass $71 \%$ was lower than the $90 \%$ of recovered from the combined acid pre-hydrolysis and enzymatic hydrolysis.

\section{Pine bark}

Enzymatic hydrolysis of non-treated pine bark was readily degraded, as smoothly as samples pre-treated with either acid or any ILs, by cellulase enzymes (Figs. 3b, $5 b)$ giving a GPR of $1.5 \mathrm{~g} \mathrm{~L}^{-1} \mathrm{~h}^{-1}$ and glucose yield of
$77 \%$. Compare to non-treated, acid pre-hydrolysis or (S) IL treatment of pine bark had no or only minimal effect on its subsequent enzymatic hydrolysis. Treatment with S-ILs slightly beneficial and improved GPRs max. $2.2 \mathrm{~g} \mathrm{~L}^{-1} \mathrm{~h}^{-1}$ and glucose yield max. $88 \% \mathrm{~g} \mathrm{~L}^{-1}$ glucose.

However, the hemicellulose recovery $88 \%$ and overall sugar yield $83 \%$ obtained from the acid pre-hydrolysis were significantly higher than obtained from either nontreated (17 or $45 \%$ ) or (S)IL-treated (23 and $53 \%$ ).

\section{Separate hydrolysis and fermentation of different lignocelluloses after treatment with either sulfuric acid or a SIL DBU-MEA-SO}

Hydrolysates obtained from the enzymatic hydrolysis of DBU-MEA-SO $\mathrm{S}_{2}$ treated or acid pre-hydrolyzed substrates were readily fermented to ethanol. Glucose present in the hydrolysates was completely consumed and converted to ethanol within first $10 \mathrm{~h}$ of fermentations (Fig. 6). Ethanol concentrations of $1.2,1.3,1.8,3.5$, and $2.7 \mathrm{~g} \mathrm{~L}^{-1}$ were obtained from the fermentation of enzymatic hydrolysates of acid pre-hydrolyzed spruce wood, pine stem wood, birch wood, reed canary grass, and pine bark, respectively. The corresponding values for the DBU-MEA-SO $\mathrm{S}_{2}$ treated substrates were $3.2,4.6,7.2,7.6$, and $3.5 \mathrm{~g} \mathrm{~L}^{-1}$, respectively. Even though the overall sugar production was higher for the combined acid and enzymatic hydrolyzed pine bark (Fig. 5b), still the overall ethanol production $3.4 \mathrm{~g} \mathrm{~L}^{-1}$ $\left(0.7 \mathrm{~g} \mathrm{~L}^{-1}\right.$ from acid hydrolysates and $2.7 \mathrm{~g} \mathrm{~L}^{-1}$ from enzymatic hydrolysates) did not exceed that obtained from the hydrolysates of IL-treated substrate (Fig. 6). Evidently, hemicellulose sugars of acid pre-hydrolysates were not consumed by the microorganism S. cerevisiae and requires an engineered strain that could use not only glucose but also other lignocellulose derived sugars.

\section{Discussion}

\section{Non-treated and acid pre-hydrolyzed substrates}

The acid pre-hydrolysis procedure, used in our study is known to produce enzymatically digestible biomass, did not benefit the subsequent enzymatic hydrolysis of especially softwood substrates. This observation is, however, consistent with observations reported by Ungurean et al. [2]. Compared to non-treated, less sugars were released from the enzymatic hydrolysis of acid pre-hydrolyzed fir wood [2]. However, the main role of dilute acid pretreatment is to solubilize hemicellulose from the biomass and to make cellulose more accessible for cellulases [2] which is also evident from our study (see Additional file 1: Tables S1-S5). The resistance of acid pre-hydrolyzed material to the hydrolytic enzymes was probably due to the changes in substrate crystallinity and increased enzyme binding capacity of lignin - the major feature that affects enzymatic degradation process [38]. 


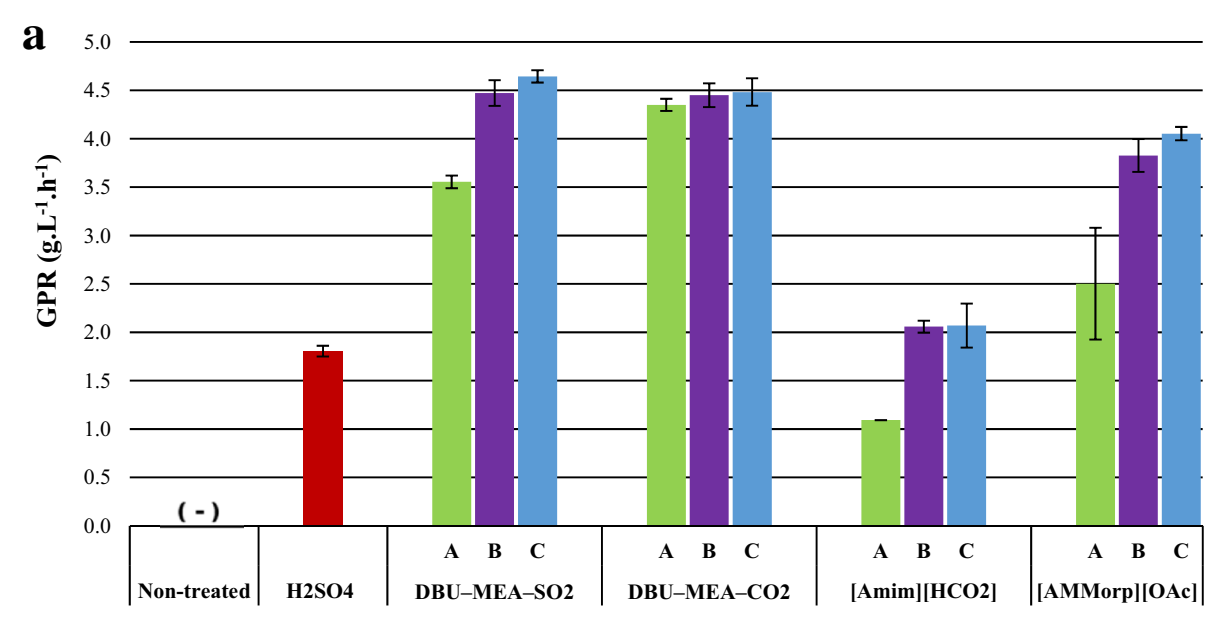

( - ) only $<0.1 \mathrm{~g} / 1$ of glucose was detected

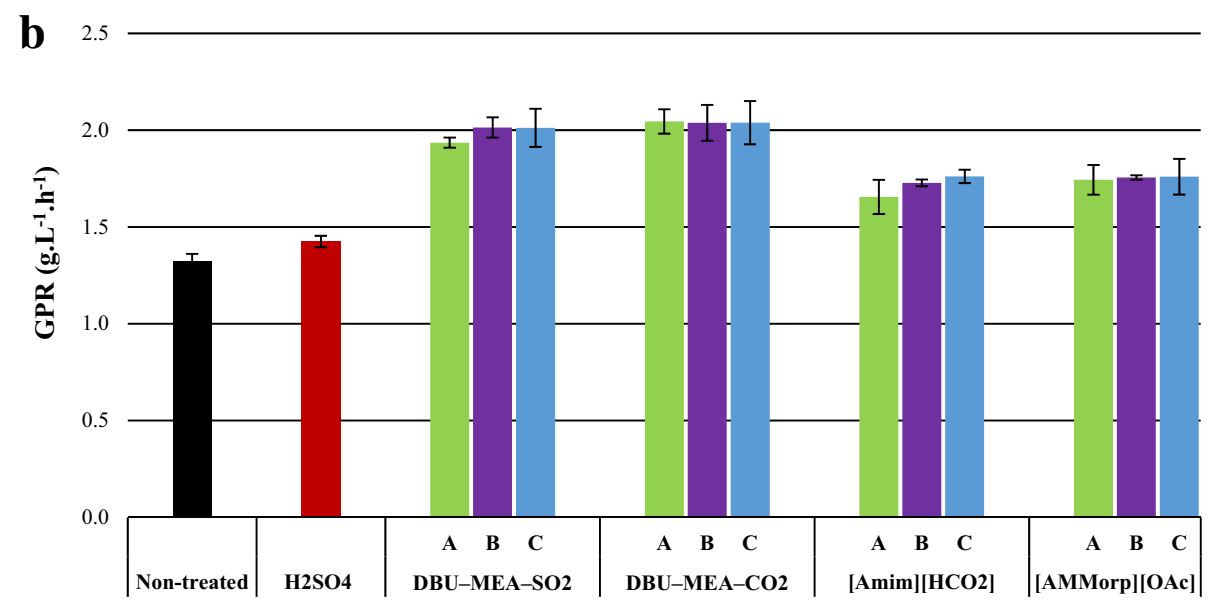

Fig. 3 Glucose production rates (GPRs) during 4-h enzymatic hydrolysis of lignocellulose substrates. a Reed canary grass; and b Pine bark. Enzymatic hydrolysis experiments were performed with either non-treated or $\mathrm{H}_{2} \mathrm{SO}_{4}$-treated (SF 4.1), or (S)IL-treated lignocelluloses. (S)IL treatments were performed at (A) SF 2.5 (B) SF 3.7 and (C) SF 4.1

Li et al. [39] investigated the efficiency of dilute acid treatment of lignocellulose substrate. Results indicated that both non-treated and dilute acid-treated samples display no changes in cellulose structure. Also, significant amount of lignin remained in the acid-treated material. Upon enzymatic hydrolysis, cellulases tend to bind on the lignin-rich surfaces-lignin can irreversibly adsorb cellulases [40] causing loss of cellulose degradation. In addition, acid treatment of spruce wood altered the lignin structure leading to increased enzyme adsorption [41, 42]. Moreover, after acid treatment, lignin or lignin carbohydrate complexes may condense on the surface of cellulose fibers [43], thus rendering the fibers less accessible to enzymes.
However, the positive effect of acid pretreatments of birch wood and canary grass could be attributed to their lignin content which contained less lignin than the softwood substrates (Table 1). However, the inhibition of enzymes lignin did not comply for pine bark. Although pine bark contained high amounts of lignin ( $40.3 \%$ dry wt.), the non-treated substrates were readily degraded by cellulase enzymes.

\section{Effect of IL treatments}

Anugwom et al. [27, 28] investigated the efficiency of SILs MEA-DBU-SO ${ }_{2}$ and MEA-DBU- $\mathrm{CO}_{2}$ for the fractionation of woody biomass (i.e. spruce and birch) and 

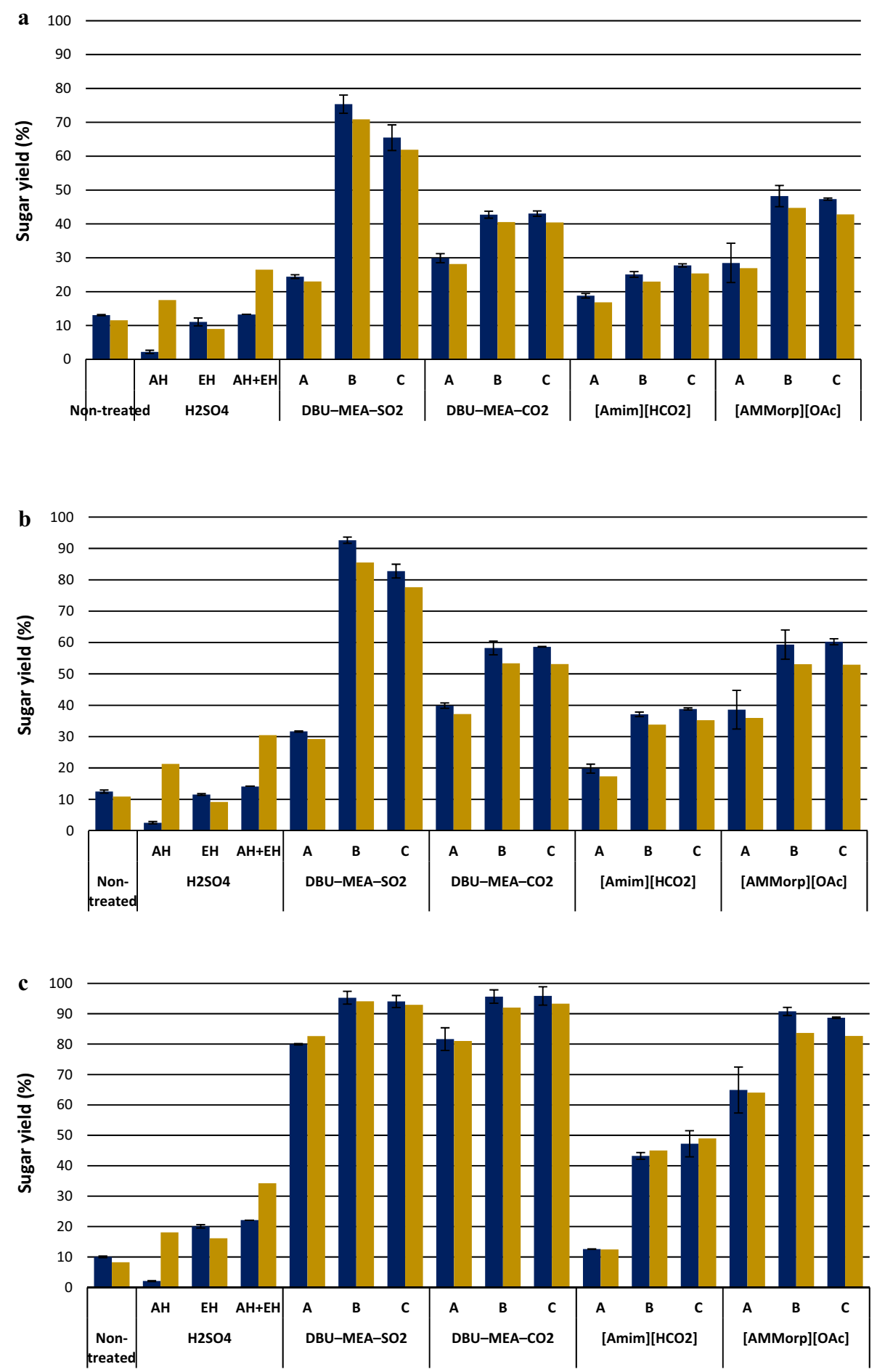

Fig. 4 Sugar yield (g sugars released/g available sugars) obtained from the hydrolysis of lignocellulose materials. Blue bars represent glucose and yellow bars represent total reducing sugars. a Spruce wood; $\mathbf{b}$ Pine stem wood; $\mathbf{c}$ Birch wood. Enzymatic hydrolysis experiments were performed with either non-treated or $\mathrm{H}_{2} \mathrm{SO}_{4}$-treated (SF 4.1), or (S) IL-treated lignocelluloses. (S)IL treatments were performed at (A) SF 2.5 (B) SF 3.7 and (C) SF 4.1. AH is acid hydrolysate, i.e., liquid fraction obtained from the acid pre-hydrolysis and $\mathrm{EH}$ is enzymatic hydrolysate of acid-treated solids 

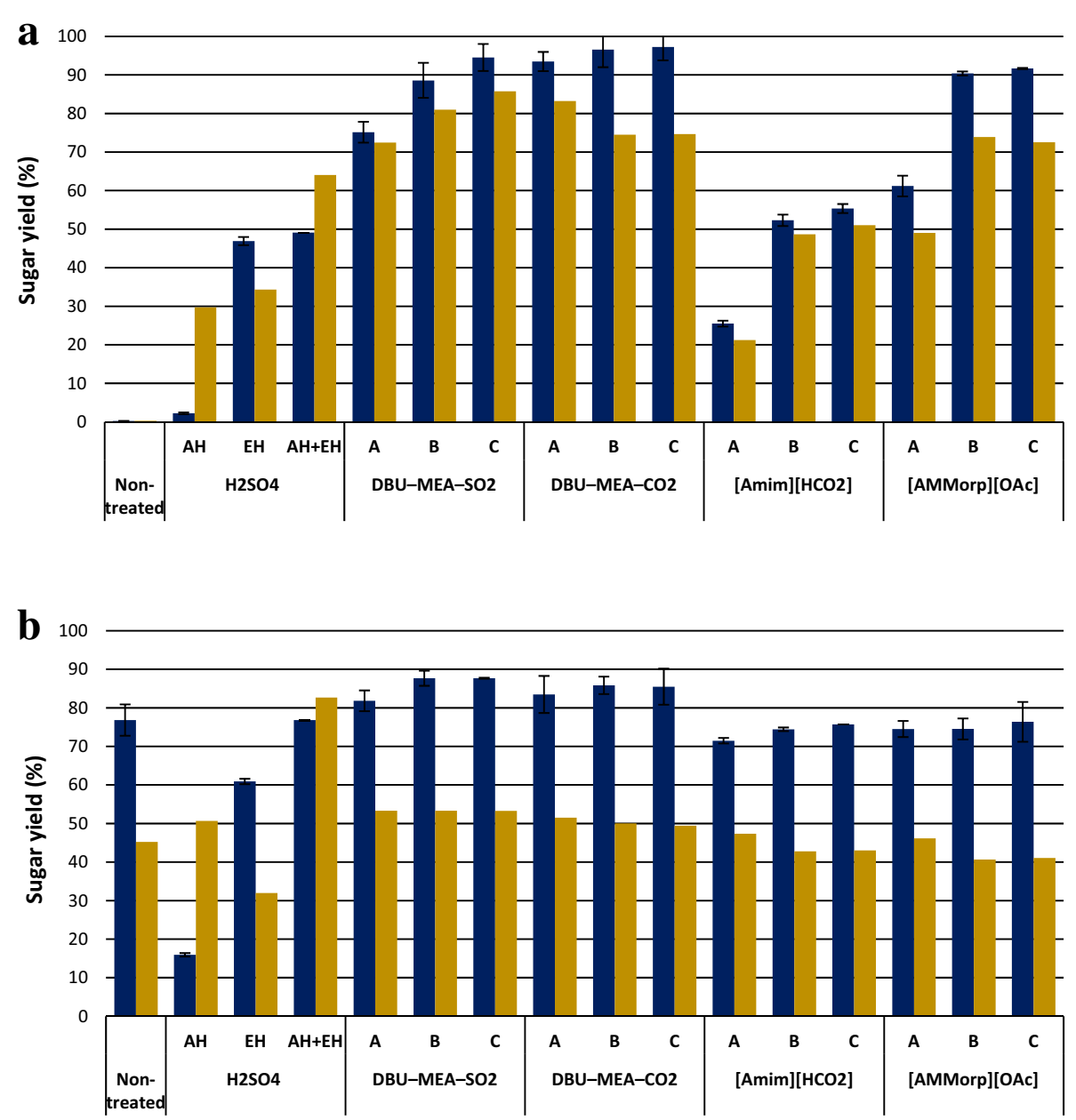

Fig. 5 Sugar yield (g sugars released/g available sugars) obtained from the hydrolysis of lignocellulose materials. Blue bars represent glucose and yellow bars represent total reducing sugars. a Reed canary grass; and $\mathbf{b}$ Pine bark. Enzymatic hydrolysis experiments were performed with either non-treated or $\mathrm{H}_{2} \mathrm{SO}_{4}$-treated (SF 4.1), or (S) LL-treated lignocelluloses. (S)IL treatments were performed at (A) SF 2.5 (B) SF 3.7 and (C) SF 4.1. AH is acid hydrolysate, i.e., liquid fraction obtained from the acid pre-hydrolysis and $\mathrm{EH}$ is enzymatic hydrolysate of acid-treated solids

reported that both these solvents could remove lignin and produce glucan enriched pulps. However, SILs MEA-DBU-SO ${ }_{2}$ was a better solvent than MEA-DBU$\mathrm{CO}_{2}$, since it was capable of removing more than $90 \%$ of lignin present in the native substrates whereas MEADBU- $\mathrm{CO}_{2}$ could remove only up to $50 \%$ [28]. Furthermore, regeneration of substrates via addition of water as anti-solvent (which is performed in our study) could reject the ILs soluble lignin in the solution [44]. Thus, creating a large cellulose accessible surface area for the subsequent enzymatic degradation with no lignin related enzyme inhibition. The improved enzymatic degradation of MEA-DBU-SO ${ }_{2}$ was more likely due to its capacity in selectively removing high amounts of lignin rather than its effect on cellulose crystallinity. In case of MEA-DBU$\mathrm{CO}_{2}$, the improved enzymatic hydrolysis is believed to be due to its synergistic effects. MEA-DBU-CO $\mathrm{CO}_{2}$ is not only capable of removing lignin but also could reduce cellulose crystallinity as evident from the experiments with Avicel cellulose. However, MEA-DBU-CO ${ }_{2}$ treatment of soft wood substrates was less effective probably due to its low lignin removing capacity.

Unlike SILs, [AMMorp][OAc] does not remove lignin. Thus, obviously, the GPRs for the [AMMorp][OAc] treated substrates were lower than the SILs-treated substrates (Figs. 2, 3). However, lignin recovery from [AMMorp][OAc]-treated substrates is rather simple whereas it would require additional efforts in case of SILs. The effect of IL $[\mathrm{Amim}]\left[\mathrm{HCO}_{2}\right]$ treatments were significantly lower than the any investigated (S)ILs. This is because $[\mathrm{Amim}]\left[\mathrm{HCO}_{2}\right]$ was less efficient in dissolving cellulose and it does not remove any lignin. 


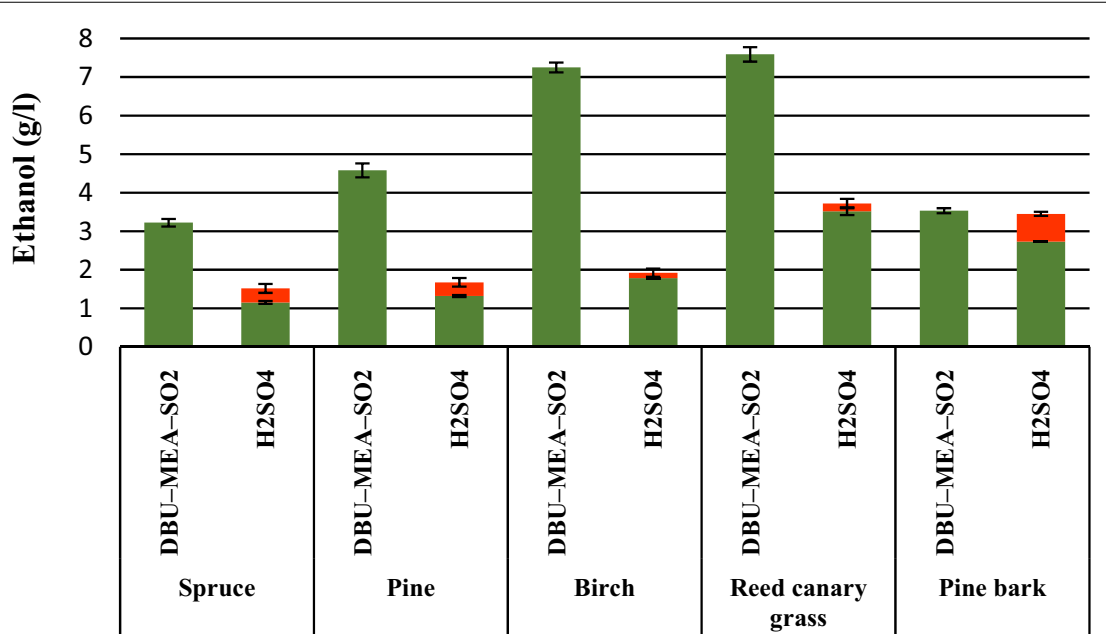

Fig. 6 Ethanol produced from the fermentations of lignocellulose hydrolysates. Green bars represent ethanol produced from the enzymatic hydrolysates and red bars represent ethanol produced from the liquid fraction of acid pre-hydrolysis. Enzymatic hydrolysis experiments were performed with lignocellulose that were first treated with either $\mathrm{H}_{2} \mathrm{SO}_{4}$ (SF 4.1) or with the SIL DBU-MEA-SO 2 (SF 4.1)

Nevertheless, despite the potential, recovery and reuse of ILs are important to make the process economically feasible. ILs are still more expensive than the conventional pretreatment solvents [6]. The recycling of ILs up to 10-20 times was claimed to allow for process costs per cycle comparable to conventional solvents, hence making ILs as cheaper alternatives as reusable solvents [45]. ILs are comparatively easy to recycle by simply removing the anti-solvent using techniques such as evaporation or distillation $[19,46,47]$. The lowvolatile nature of ILs permits distillation of the volatile substances, thus allowing for recovery [48, 49]. It has been already shown that the ILs can be recovered and reused at least up to 5-7 times without decline in their efficiency [22, 49]. However, recovery and reuse of ILs are often a question considering scaled up production of ILs. Nonetheless, ILs that have undergone cellulose regeneration are composed of not only dissolved IL and the anti-solvent but also contain soluble biomass compounds (e.g., lignin, soluble carbohydrates with low molecular weight, degradation products, extractives and others) that were not precipitated in the regeneration step. Recovery of these dissolved compounds is important; for instance, the recovered lignin may potentially serve as a raw material in the production of polymeric materials, and can be tedious.

\section{Influence of IL treatment conditions on enzymatic hydrolysis}

The conditions used for the IL treatments (Table 2) were selected to gain more information about the impact of treatment temperature and residence time on the IL treatments effect on subsequent substrate hydrolysis efficiency.

At a constant amount, i.e., 5 (w/w) \% of biomass loading and upon fixed (S)IL pretreatment time, increasing pretreatment temperature favored and greatly enhanced the enzymatic digestion of lignocellulose substrates similar to observations by Hou et al. [50]. After IL treatment of birch and pine wood, at moderate conditions, the substrates were swollen but not dissolved [51]. It is believed that, at low pretreatment temperatures, the IL molecules mainly swell and disrupt cellulose I lattice, with no appreciable amount of cellulose chains being released into the IL solution. It is also speculated that, at low temperatures, the multilayered structures of plant cell wall and lignin network inhibit dissociation of cellulose chains

Table 2 Summary of conditions used for the pretreatment of different (lingo)cellulose substrates

\begin{tabular}{|c|c|c|c|c|}
\hline \multirow[t]{2}{*}{ Solvent } & \multicolumn{4}{|c|}{ Temperature and time } \\
\hline & $\begin{array}{l}120^{\circ} \mathrm{C} \\
(90 \mathrm{~min})\end{array}$ & $\begin{array}{l}160{ }^{\circ} \mathrm{C} \\
(90 \mathrm{~min})\end{array}$ & $\begin{array}{l}180^{\circ} \mathrm{C} \\
(60 \mathrm{~min})\end{array}$ & $\begin{array}{l}205^{\circ} \mathrm{C} \\
(10 \mathrm{~min})\end{array}$ \\
\hline $\mathrm{DBU}-\mathrm{MEA}-\mathrm{SO}_{2}$ & $\checkmark$ & $\checkmark$ & $\checkmark$ & - \\
\hline DBU-MEA-CO & $\checkmark$ & $\checkmark$ & $\checkmark$ & - \\
\hline$[\mathrm{Amim}]\left[\mathrm{HCO}_{2}\right]$ & $\checkmark$ & $\checkmark$ & $\checkmark$ & - \\
\hline [AMMorp][OAc] & $\checkmark$ & $\checkmark$ & $\checkmark$ & - \\
\hline $\mathrm{H}_{2} \mathrm{SO}_{4}$ & - & - & - & $\checkmark$ \\
\hline $\mathrm{SF}^{\mathrm{a}}$ & 2.5 & 3.7 & 4.1 & 4.1 \\
\hline
\end{tabular}

a Severity factor $(\mathrm{SF}): \mathrm{SF}=\log \left(t \cdot \exp \left(\left(T-T_{\text {ref }}\right) / 14.75\right) ; t\right.$ treatment time in minutes; $T$ treatment temperature; $T_{\text {ref }}$ reference temperature, i.e., $100^{\circ} \mathrm{C} ; 14.75$ is an empirically determined constant 
[50]. However, at higher temperatures, the plant cell walls were destroyed and cellulose chains were released into the IL solution and the highly crystalline cellulose I was transformed into less crystalline cellulose II [52]. Hence, evidently, the highest amount of reducing sugars (and best glucose production rates) was obtained for the substrates treated at 160 and $180{ }^{\circ} \mathrm{C}$ (Figs. 2, 3, 4, 5). Shorter (S)IL treatment time (instead of $90 \mathrm{~min} 60 \mathrm{~min}$ ) an increase in temperature (from 160 to $180{ }^{\circ} \mathrm{C}$ ) had no significant effect in terms of subsequent enzymatic hydrolysis. In conclusion, high temperatures and short residence time upon pretreatment of lignocelluloses gave good results.

In general, from our study it was clear that, except or pine bark, lignin is a major barrier and plays an important role in the sugar extraction from lignocellulose substrates. There was a very close correlation between effect of efficiency of pretreatment solvent and lignin content of the lignocellulose. For example for lignin-rich soft wood substrates, lignin-specific SIL DBU-MEA-SO $\mathrm{S}_{2}$ was the most efficient pretreatment solvent. Nevertheless, in case of the species with low lignin content (hard wood and reed canary grass), DBU-MEA- $\mathrm{CO}_{2}$ or [AMMorp] [OAc] was the best pretreatment medium. Evidently, the differences in the substrate lignin content have an impact on the results of any pretreatment as reported before [53].

\section{Conclusions}

The potential of different (S)ILs as pretreatment solvents upon conversion of several lignocelluloses into bioethanol was investigated. It was demonstrated that (S)IL treatments could significantly improve the enzymatic hydrolysis of biomass. SILs were in relative terms better pretreatment solvents, especially in case of softwood substrates. The SIL DBU-MEA-SO ${ }_{2}$ was the best pretreatment media for woody substrates liberating both glucose and hemicellulose sugars. Nevertheless, in case of Pine bark, the combined acid treatment and enzymatic hydrolysis gave better results than what could be achieved with any (S)IL preprocessing. However, hydrolysates obtained from the enzymatic hydrolysis of (S)ILtreated lignocelluloses were readily fermented to ethanol and the yields were up to four times higher compared to the case when combined acid and enzymatic hydrolysis was employed. Thus, (S)IL-mediated preprocessing of lignocellulosic biomass can offer advantages over conventional acid treatments.

However, even though the (S)ILs investigated in this study were highly efficient, still challenges remain in their applications such as recovery of any (S)IL-degraded species (notably lignin and sugar polysaccharides) and potentially challenging recycling of (S)ILs.

\section{Methods}

\section{Substrates}

A variety of lignocellulose materials, including those of soft wood, hard wood and agriculture residues were targeted in the current study. Norway spruce wood, pine stem wood, birch saw dust, pine bark, and reed canary grass were the species studied. The substrates were first air dried at room temperature until a constant weight and moisture content less than $10(\mathrm{w} / \mathrm{w}) \%$, was achieved. Afterwards, they were milled and sieved to an even particle size $<1 \mathrm{~mm}$ using a Wiley mill and stored in sealed plastic bags at room temperature until further use. The dry-matter content of the substrates was determined using a Sartorius MA30 Electronic Moisture Analyzer (Germany) through heating by infrared rays and determination of weight loss. Along with native lignocellulose materials, a commercial microcrystalline cellulose substrate Avicel ${ }^{\circledR}$ PH-101 (Sigma-Aldrich) was also used in the investigation for the sake of comparison.

The chemical composition of lignocelluloses in terms of structural carbohydrate content, lignin and extractives were analyzed according to National Renewable Energy Laboratory (NREL) analytical procedures $[54,55]$.

\section{Ionic liquids}

SILs DBU-MEA-SO ${ }_{2}$ and DBU-MEA- $\mathrm{CO}_{2}$ were prepared as described in Anugwom et al. [27, 28]. An equimolar mixture of DBU and MEA was bubbled with either $\mathrm{SO}_{2}$ or $\mathrm{CO}_{2}$ gas under rigorous stirring and the reactions were performed until the complete formation of SILs. $[\mathrm{Amim}]\left[\mathrm{HCO}_{2}\right]$ was synthesised as reported earlier in Soudham et al. [33].

The new IL [AMMorp] $[O A c]$ was prepared as follows: Amberlite IRA-400(R-OH) (10.0 g in deionized water) was loaded in a chromatography column $(20 \times 1.5 \mathrm{~cm})$ and then $1.0 \mathrm{M}$ sodium acetate solution $(100 \mathrm{~mL})$ was passed through the column to facilitate ion exchange. After, the column was thoroughly washed with deionized water until the eluent $\mathrm{pH} \sim 7$ was obtained. The corresponding bromide precursor, $\mathrm{N}$-allyl- $\mathrm{N}$-methylmorpholinium bromide (4.44 g in $50 \mathrm{~mL}$ deionized water), solution was carefully loaded and passed through the column followed by deionized water $(50 \mathrm{~mL})$. The eluent containing [AMMorp][OAc] was collected and water evaporated. Then the IL was dried at $60{ }^{\circ} \mathrm{C}$ under high vacuum $\left(4 \times 10^{-2} \mathrm{mbar}\right)$ to remove residual water.

\section{Pretreatment procedures}

Pretreatment of different cellulosic substrates $(50 \mathrm{mg})$ with either various IL solvents $(950 \mathrm{mg})$ or $1(\mathrm{w} / \mathrm{w}) \%$ $\mathrm{H}_{2} \mathrm{SO}_{4}(950 \mathrm{mg}$ ) were performed in $12 \mathrm{~mL}$ borosilicate glass tubes with polytetrafluoroethylene (PTFE)-lined screw caps. A pressure reactor (Teflon lined stainless 
steel, homemade, $500 \mathrm{~mL}$ ) with silicon oil was preheated to a desired treatment temperature using a furnace $\left(T_{\max }<1100{ }^{\circ} \mathrm{C}\right)$ equipped with B 180 controller and $\mathrm{NiCr}-\mathrm{Ni}$ thermocouple (Nabertherm Muffle furnace, Model No. LVT 9/11, Germany). Glass tubes with cellulosic substrates and ionic liquids were then immersed into the preheated reactor and closed tightly. The reactor was then placed in the furnace and the desired reaction conditions were set (Table 2). After treatment, the reactor was removed from the furnace; the tubes were removed from the reactor and allowed to cool to room temperature. The IL-treated cellulose rich substrates were then precipitated by simply adding $6 \mathrm{~g}$ of anti-solvent (in our case deionized water) to the pretreated solutions. Afterwards, the solids were separated by vigorous mixing and centrifugation for $7 \mathrm{~min}$ and $3000 \mathrm{rpm}$ (Allegra ${ }^{\circledR}$ 25R centrifuge, BECKMAN COULTER, USA). The IL rich supernatants were decanted and the solids were subsequently washed as described above, using $3 \times 6 \mathrm{~g}$ anti-solvent and $1 \times 6 \mathrm{~g} 50 \mathrm{mM}$ citrate buffer $\mathrm{pH}$ 5.8. These are hereafter referred to as regenerated substrates. In the case of lignocelluloses pre-hydrolyzed with $\mathrm{H}_{2} \mathrm{SO}_{4}$, the solid and liquid fractions were separated by centrifugation. The collected liquid fractions (acid hydrolysates-AHs) were stored at $-80{ }^{\circ} \mathrm{C}$ and the solids were washed with deionized water and citrate buffer as mentioned earlier. The obtained regenerated substrates from IL treatments and the solids from acid pre-hydrolysis (S-AH) were then lyophilized (Alpha 2-4 LSC Freeze Dryer, Martin Christ Gefriertrocknungsanlagen $\mathrm{GmbH}$, Germany) to remove any residual liquids, thus avoiding uneven dilutions upon their enzymatic hydrolysis.

To compare the efficiency of different treatments used in this study, the parameter severity factor (SF) was employed, which incorporates the treatment time and temperature (see the equation below). It is generally used to assess various individual lignocellulose pretreatment strategies [56].

$$
\mathrm{SF}=\log \left(t \cdot \exp \left(\left(T-T_{\text {ref }}\right) / 14.75\right)\right)
$$

In the above equation, $t$ is the treatment time in minutes, $T$ is the treatment temperature, $T_{\text {ref }}$ is the reference temperature (i.e., $100{ }^{\circ} \mathrm{C}$ ) and 14.75 is an empirically determined constant.

\section{Enzymatic hydrolysis}

Enzymatic hydrolysis experiments of non-treated and regenerated cellulosic substrates were carried out in $12 \mathrm{~mL}$ glass tubes with $930 \mathrm{mg}$ of $50 \mathrm{mM}$ citrate buffer pH 5.8 and $20 \mathrm{mg}$ of Cellic CTec2, activity $128.6 \mathrm{FPU} / \mathrm{g}$, state-of-the-art enzyme mix (Novozymes). Hydrolysis reactions were performed for $48 \mathrm{~h}$ in a shaking incubator
(IKA ${ }^{\circledR}$ KS 4000, control IKA ${ }^{\circledR}$-Werke GmbH \& Co. KG, Germany) set at $50{ }^{\circ} \mathrm{C}$ and $200 \mathrm{rpm}$. At defined time intervals $(4,24$, and $48 \mathrm{~h}$ after the addition of enzymes), samples of $50 \mu \mathrm{L}$ (enzymatic hydrolysates-EHs) were collected from the hydrolysis systems and stored at $-80{ }^{\circ} \mathrm{C}$.

\section{Separate hydrolysis and fermentation}

Lignocellulose samples, $0.25 \mathrm{~g}$ (dry weight), were pretreated at a severity factor of 4.1 (Table 2) with either the SIL DBU-MEA-SO $(4.75 \mathrm{~g})$ or $1(\mathrm{w} / \mathrm{w}) \% \mathrm{H}_{2} \mathrm{SO}_{4}$ $(4.75 \mathrm{~g})$ in $10 \mathrm{~mL}$ glass tubes. Hydrolysis of regenerated substrates $0.3 \mathrm{~g}$, obtained after the treatments and lyophilization, was performed in the presence of citrate buffer $\mathrm{pH} 5.8$ (5.58 g) and enzyme (0.12 g) mix. Thus, the pretreatments and enzymatic hydrolysis experiments were performed (as described in earlier sections) with an increased overall reaction volume, but in equal concentrations. After enzymatic hydrolysis, the solid and liquid fractions were separated by centrifugation and the sugarrich liquid fractions were used for ethanol fermentations as described below.

The yeast S. cerevisiae, Thermosacc inoculum was prepared in a $2 \mathrm{~L}$ cotton-plugged shake flask with $1 \mathrm{~L}$ YPD medium $\left(10 \mathrm{~g} \mathrm{~L}^{-1}\right.$ yeast extract, $20 \mathrm{~g} \mathrm{~L}^{-1}$ peptone, $20 \mathrm{~g} \mathrm{~L}^{-1} \mathrm{D}$-glucose). The medium was inoculated and incubated with agitation $(200 \mathrm{rpm})$ at $30{ }^{\circ} \mathrm{C}$ and the cells were harvested in late exponential growth phase by centrifugation (Hermle Z206A, Hermle Labortechnik $\mathrm{GmbH}$, Wehingen, Germany) at $1500 g$ for $5 \mathrm{~min}$. The harvested cells were concentrated and re-suspended in an appropriate amount of sterile water to achieve a cell density of $27 \mathrm{~g} \mathrm{~L}^{-1}$ (dry weight). Fermentations of liquid hydrolysates, obtained from both the acid pre-hydrolysis and enzymatic hydrolysis, were performed in $12 \mathrm{~mL}$ screw capped plastic tubes. Sugar-rich liquid hydrolysates $(2.3 \mathrm{~mL}$ of each) were added to the tubes along with $0.05 \mathrm{~mL}$ nutrient solution $\left(75 \mathrm{~g} \mathrm{~L}^{-1}\right.$ yeast extract, $37.5 \mathrm{~g} \mathrm{~L}^{-1}\left(\mathrm{NH}_{4}\right)_{2} \mathrm{HPO}_{4}, 1.875 \mathrm{~g} \mathrm{~L}^{-1} \mathrm{MgSO}_{4} \cdot 7 \mathrm{H}_{2} \mathrm{O}$, $119.1 \mathrm{~g} \mathrm{~L}^{-1} \mathrm{NaH}_{2} \mathrm{PO}_{4} \cdot \mathrm{H}_{2} \mathrm{O}$ ), and $0.15 \mathrm{~mL}$ of yeast inoculum. Thus, the fermentation broths contained a total liquid volume of $2.5 \mathrm{~mL}$ and had a yeast cell density of $1.6 \mathrm{~g} \mathrm{~L}^{-1}$ dry weight. After inoculation, the tubes were incubated at $30{ }^{\circ} \mathrm{C}$ and stirred (at $200 \mathrm{rpm}$ ) in an orbital shaking incubator (IKA-Werke) for $24 \mathrm{~h}$. Samples of $100 \mu \mathrm{L}$ were collected at defined time intervals and stored at $-80^{\circ} \mathrm{C}$ until further analysis.

\section{Analysis}

Samples collected from different experiments of this study were centrifuged (Centrifuge: Thermo Scientific, Germany) at $21,000 \mathrm{~g}$ for $5 \mathrm{~min}$ and the supernatants were used for chemical analysis by either using ion 
chromatography (IC; ICS 3000, Dionex Corporation, USA) or High-Performance Liquid Chromatography (HPLC; Dionex ${ }^{\mathrm{TM}}$ UltiMate 3000, Dionex Corporation, USA).

The monosaccharide (i.e., arabinose, galactose, glucose, mannose, and xylose) concentrations were analyzed in a similar manner as in Wang et al. [57] by Ion Chromatography using a CarboPac PA1 column (Bio-Rad Laboratories). Ethanol concentrations were measured by HPLC equipped with a Rezex ROA-Organic acid $\mathrm{H}$ column (containing sulfonated styrene-divinylbenzene spheres in $8 \%$ cross-link forms, $300 \times 7.8 \mathrm{~mm}$, Phenomenex ${ }^{\circledR}$, USA) as previously described in Soudham et al. [58].

\section{Additional file}

Additional file 1: Tables S1-S5. Sugars released from the hydrolysis of lignocellulose materials. Sugars released from the enzymatic hydrolysis of lignocelluloses non-treated and treated with either $\mathrm{H}_{2} \mathrm{SO}_{4}\left(205^{\circ} \mathrm{C}\right.$ for 10 min) or (S) IL solvents at (A) $120^{\circ} \mathrm{C}$ for 90 min (B) $160{ }^{\circ} \mathrm{C}$ for 90 min and (C) $180^{\circ} \mathrm{C}$ for $60 \mathrm{~min}$. Sugars released from the acid pre-hydrolysis are also shown. $\mathrm{AH}$ is acid hydrolysate and $\mathrm{EH}$ is enzymatic hydrolysate

\begin{abstract}
Abbreviations
[Amim] $\left[\mathrm{HCO}_{2}\right]$ : 1-allyl-3-methylimidazolium formate; [AMMorp][OAc]: N-allyl$\mathrm{N}$-methylmorpholinium acetate; [ $\mathrm{C}_{2}$ mim] [OAc]: 1-ethyl-3-methylimidazolium acetate; $\left[\mathrm{C}_{4}\right.$ mim $] \mathrm{Cl}$ : 1-butyl-3-methylimidazolium chloride; $\mathrm{AH}$ : acid hydrolysate; DBU: 1,8-diazabicycloundec-7-ene; EH: enzymatic hydrolysate; GPR: glucose production rate; IL: ionic liquid; MEA: monoethanolamine; RCG: reed canary grass; S-APH: solids obtained from the acid pre-hydrolysis; SF: severity factor; SIL: switchable ionic liquid.
\end{abstract}

\section{Authors' contributions}

VPS is responsible for designing and performing all the experiments including chemical composition of biomass, pretreatment, enzymatic hydrolysis, fermentations, chemical analysis, and data analysis; also, the manuscript was prepared by him. DGR and IA were responsible for preparing the IL solvents. $\mathrm{TB}, \mathrm{CL}$, and J-PM wrote parts of the manuscript and revised it critically for important intellectual content. All authors read and approved the final manuscript.

\section{Author details}

${ }^{1}$ Department of Chemistry, Technical Chemistry and Sustainable Chemical Technology, Chemical-Biological Centre, Umeå University, 90187 Umeå, Sweden. ${ }^{2}$ Department of Chemical and Biological Engineering, Chalmers University of Technology, Kemivägen 10, 41296 Göteborg, Sweden. ${ }^{3}$ Laboratory of Industrial Chemistry and Reaction Engineering, Johan Gadolin Process Chemistry Centre, Åbo Akademi University, 20500 Åbo-Turku, Finland.

\section{Acknowledgements}

The authors acknowledge Umeå University, Kempe Foundations and Bio4Energy program. This work is a part of activities of the Wallenberg Wood Science Center and the Johan Gadolin Process Chemistry Centre at Åbo Akademi University.

\section{Compliance with ethical guidelines}

\section{Competing interests}

The authors declare that they have no competing interests.

Received: 21 April 2015 Accepted: 11 August 2015

Published online: 04 September 2015

\section{References}

1. Binder JB, Raines RT (2010) Fermentable sugars by chemical hydrolysis of biomass. PNAS Appl Biol Sci Chem 107:4516-4521

2. Ungurean M, Fițigău F, Paul C, Ursoiu A, Peter F (2011) lonic liquid pretreatment and enzymatic hydrolysis of wood biomass. World Acad Sci Eng Technol 52:387-391

3. Ragauskas AJ, Beckham GT, Biddy MJ, Chandra R, Chen F, Davis MF, Davison BH, Dixon RA, Gilna P, Keller M, Langan P, Naskar AK, Saddler JN, Tschaplinski TJ, Tuskan GA, Wyman CE (2014) Lignin valorization: improving lignin processing in the biorefinery. Science 344:6185

4. Zha Y, Punt PJ (2013) Exometabolomics approaches in studying the application of lignocellulosic biomass as fermentation feedstock. Metabolites 3:119-143

5. Alvira P, Tomás-Pejó E, Ballesteros M, Negro MJ (2010) Pretreatment technologies for an efficient bioethanol production process based on enzymatic hydrolysis: a review. Bioresour Technol 101:4851-4861

6. Da Costa Lopes AM, João KG, Bogel-Łukasik E, Roseiro LB, Bogel-Łukasik R (2013) Pretreatment and fractionation of wheat straw using various ionic liquids. J Agric Food Chem 61(33):7874-7882

7. Galbe M, Zacchi G (2007) Pretreatment of lignocellulosic materials for efficient bioethanol production. Adv Biochem Engin Biotechnol 108:41-65

8. Mäki-Arvela P, Anugwoma I, Virtanen P, Sjoholm R, Mikkola JP (2010) Dissolution of lignocellulosic materials and its constituents using ionic liquids - a review. Ind Crops Prod 32:175-201

9. Sathitsuksanoh N, George A, Zhang YHP (2012) New lignocellulose pretreatments using cellulose solvents: a review. J Chem Technol Biotechnol. doi:10.1002/jctb.3959

10. Zhang B, Shahbazi A (2011) Recent developments in pretreatment technologies for production of lignocellulosic biofuels. J Pet Environ Biotechnol 2(2):111

11. Zhu S, Yu P, Wang Q, Cheng B, Chen J, Wu Y (2013) Breaking the barriers of lignocellulosic ethanol production using ionic liquid technology. Bioresources 8(2):1510-1512

12. Bozell JJ (2010) An evolution from pretreatment to fractionation will enable successful development of the integrated biorefinery. Bioresources 5(3):1326-1327

13. Argyropoulos DS, Raleigh NC (2013) High value lignin derivatives, polymers, and copolymers and use thereof in thermoplastic, thermoset, composite, and carbon fiber applications. USPTO Patent: US 13771653. October 3

14. Kumar S, Singh SP, Mishra IM, Adhikari DK (2009) Recent advances in production of bioethanol from lignocellulosic biomass. Chem Eng Technol 32(4):517-526

15. Raganati F, Curth S, Götz P, Olivieri G, Marzocchella A (2012) Butanol production from lignocellulosic-based hexoses and pentoses by fermentation of Clostridium Acetobutylicum. Chem Eng Trans 27:91-96

16. Tashiro Y, Yoshida T, Noguchi T, Sonomoto K (2013) Recent advances and future prospects for increased butanol production by acetone-butanolethanol fermentation. Eng Life Sci 00:1-14

17. Wyman CE (1994) Ethanol from lignocellulosic biomass: technology, economics, and opportunities. Bioresour Technol 50:3-16

18. Liu CZ, Feng Wang, Stiles AR, Guo C (2012) Ionic liquids for biofuel production: opportunities and challenges. Appl Energy 92:406-414

19. Brandt A, Gräsvik J, Halletta JP, Welton T (2013) Deconstruction of lignocellulosic biomass with ionic liquids. Green Chem 15(3):550-583

20. Leskinen T, King AW, Kilpeläinen I, Argyropoulos DS (2013) Fractionation of lignocellulosic materials using ionic liquids: Part 2. Effect of particle size on the mechanisms of fractionation. Ind Eng Chem Res 52(11):3958-3966

21. Da Costa Lopes AM, João KG, Morais AR C, Bogel-Łukasik E, Bogel-Łukasik $\mathrm{R}$ (2013b) lonic liquids as a tool for lignocellulosic biomass fractionation. Sustain Chem Process 1. doi:10.1186/2043-7129-1-3

22. Da Costa Lopes AM, Joao KG, Rubik DF, Bogel-Łukasik E, Duarte LC, Andreaus J, Bogel-Łukasik R (2013) Pre-treatment of lignocellulosic biomass using ionic liquids: wheat straw fractionation. Bioresour Technol 142:198-208

23. Magalhães da Silva SP, da Costa Lopes AM, Roseiro LB, Bogel-Lukasik R (2013) Novel pre-treatment and fractionation method for lignocellulosic biomass using ionic liquids. RSC Adv 3:16040-16050

24. George A, Brandt A, Tran K, Zahari SMS-NS, Klein-Marcuschamer D, Sun N, Sathitsuksanoh N, Shi J, Stavila V, Parthasarathi R, Singh S, Holmes BM, 
Welton T, Simmons BA, Hallett JP (2015) Design of low-cost ionic liquids for lignocellulosic biomass pretreatment. Green Chem 17:1728-1734

25. Chen L, Sharifzadeh M, MacDowell N, Welton T, Shah N, Hallett JP (2014) Inexpensive ionic liquids: $\left[\mathrm{HSO}_{4}\right]^{-}$-based solvent production at bulk scale. Green Chem 16(6):3098-3106

26. Da Costa Lopes AM, Bogel-Łukasik R (2015) Acidic ionic liquids as sustainable approach of cellulose and lignocellulosic biomass conversion without additional catalysts. Chem Sus Chem 8:947-965

27. Anugwom I, Eta V, Virtanen P, Maki-Arvela P, Hedenstrom M, Yibo M, Hummel M, Sixta H, Mikkola JP (2014) Towards optimal selective fractionation for Nordic woody biomass using novel amine-organic superbase derived switchable ionic liquids (SILs). Biomass Bioenergy 70:373-381

28. Anugwom I, Eta V, Virtanen P, Mki-Arvela P, Hedenstrçm M, Hummel M, Sixta H, Mikkola JP (2014) Switchable ionic liquids as delignification solvents for lignocellulosic materials. Chem Sus Chem 7:1170-1176

29. Groff D, George A, Sun N, Sathitsuksanoh N, Bokinsky G, Simmons BA, Holmes BM, Keasling JD (2013) Acid enhanced ionic liquid pretreatment of biomass. Green Chem 15:1264-1267

30. Lozano P, Bernal B, Recioa I, Belleville M-P (2012) A cyclic process for full enzymatic saccharification of pretreated cellulose with full recovery and reuse of the ionic liquid 1-butyl-3-methylimidazolium chloride. Green Chem 14:2631-2637

31. Sun N, Rahman M, Qin Y, Maxim ML, Rodríguez H, Rogers RD (2009) Complete dissolution and partial delignification of wood in the ionic liquid1-ethyl-3-methylimidazolium acetate. Green Chem 11:646-655

32. Ungurean M, Csanádi Z, Gubicza L, Péter F (2014) An integrated process of ionic liquid pretreatment and enzymatic hydrolysis of lignocellulosic biomass with immobilised cellulase. Bioresources 9(4):6100-6116

33. Soudham VP, Gräsvik J, Alriksson B, Mikkola J-P, Jönsson LJ (2013) Enzymatic hydrolysis of Norway spruce and sugarcane bagasse after treatment with 1-allyl-3-methylimidazolium formate. J Chem Technol Biotechnol 88(12):2209-2215

34. Su W (2012) A study of cellulose dissolution in ionic liquidwater brines. Umeå University. Available <http://www.diva-portal.org/smash/get/ diva2:545389/FULLTEXT01.pdf>

35. Nunes E, Quilhó T, Pereira H (1999) Anatomy and chemical composition of Pinus pinea L. bark. Ann For Sci 56:479-484

36. Räisänen T, Athanassiadis D (2013) Basic chemical composition of the biomass components of pine, spruce and birch. <http://www.biofuelregion. se>

37. Valentín L, Kluczek-Turpeinen B, Willför S, Hemming J, Hatakka A, Steffen K, Tuomela M (2010) Scots pine (Pinus sylvestris) bark composition and degradation by fungi: potential substrate for bioremediation. Bioresour Technol 101:2203-2209

38. Yang B, Dai Z, Ding SY, Wyman CE (2011) Enzymatic hydrolysis of cellulosic biomass. Biofuels 2(4):421-450

39. Li C, Knierim B, Manisseri C, Arora R, Scheller HV, Auer M, Vogel KP, Simmons BA, Singh S (2010) Comparison of dilute acid and ionic liquid pretreatment of switchgrass: Biomass recalcitrance, delignification and enzymatic saccharification. Bioresour Technol 101(13):4900-4906

40. Lee SH, Doherty TV, Linhardt RJ, Dordick JS (2009) Ionic liquid-mediated selective extraction of lignin from wood leading to enhanced enzymatic cellulose hydrolysis. Biotechnol Bioeng 102(5):1368-1376

41. Rahikainen J, Mikander S, Marjamaa K, Tamminen T, Lappas A, Viikari L et al (2011) Inhibition of enzymatic hydrolysis by residual lignins from softwood-study of enzyme binding and inactivation on lignin-rich surface. Biotechnol Bioeng 08(12):2823-2834
42. Rahikainen J, Martin-Sampedro R, Heikkinen H, Rovio S, Marjamaa K, Tamminen T, Rojas OJ, Kruus K (2013) Inhibitory effect of lignin during cellulose bioconversion: the effect of lignin chemistry on non-productive enzyme adsorption. Bioresour Technol 133:270-278

43. Zhu L, O'Dwyer JP, Chang VS, Granda CB, Holtzapple MT (2008) Structural features affecting biomass enzymatic digestibility. Bioresour Technol 99:3817-3828

44. Singh S, Simmons BA, Vogel KP (2009) Visualization of biomass solubilization and cellulose regeneration during ionic liquid pretreatment of switchgrass. Biotechnol Bioeng 104:68-75

45. Tadesse H, Luque R (2011) Advances on biomass pretreatment using ionic liquids: an overview. Energy Environ Sci 4:3913-3929

46. Abu-Eishah SI (2011) Ionic liquids recycling for reuse. In: Handy S (ed) Ionic liquids-classes and properties: InTech

47. Lan Mai N, Ahn K, Koo Y-M (2014) Methods for recovery of ionic liquidsa review. Process Biochem 49:872-881

48. Vancov T, Alston A-S, Brown T, Mclntosh S (2012) Use of ionic liquids in converting lignocellulosic material to biofuels. Renew Energy 45:1-6

49. Weerachanchai P, Lee JM (2014) Recyclability of an ionic liquid for biomass pretreatment. Bioresour Technol 169:336-343

50. Hou XD, Smith TJ, Li N, Zong MH (2012) Novel renewable ionic liquids as highly effective solvents for pretreatment of rice straw biomass by selective removal of lignin. Biotechnol Bioeng 109(10):2484-2493

51. Mou HY, Orblin E, Kruus K, Fardim P (2013) Topochemical pretreatment of wood biomass to enhance enzymatic hydrolysis of polysaccharides to sugars. Bioresour Technol 142:540-545

52. Zhang J, Wang Y, Zhang L, Zhang R, Liu G, Cheng G (2014) Understanding changes in cellulose crystalline structure of lignocellulosic biomass during ionic liquid pretreatment by XRD. Bioresour Technol 151:402-405

53. Samayam IP, Hanson BL, Langan P, Schall CA (2011) lonic-liquid induced changes in cellulose structure associated with enhanced biomass hydrolysis. Biomacromolecules 12 (8):3091-3098

54. Sluiter A, Hames B, Ruiz R, Scarlata C, Sluiter J, Templeton D, Crocker D (1998b) Determination of structural carbohydrates and lignin in biomass. Laboratory Analytical Procedure (LAP). Technical Report NREL/TP-51042618. Golden, Colorado: National Renewable Energy Laboratory

55. Sluiter A, Ruiz R, Scarlata C, Sluiter J, Templeton D (1998a) Determination of extractives in biomass. Laboratory Analytical Procedure (LAP). Technical Report NREL/TP-510-42619. Golden, Colorado: National Renewable Energy Laboratory

56. Pedersen M, Meyer AS (2010) Lignocellulose pretreatment severity relating $\mathrm{pH}$ to biomatrix opening. New Biotechnol 27(6):739-750

57. Wang Y, Wei L, Li K, Ma Y, Ma N, Ding S, Wang L, Zhao D, Yan B, Wan W, Zhang Q, Wang X, Wang J, Li H (2014) Lignin dissolution in dialkylimidazolium-based ionic liquid-water mixtures. Bioresour Technol 170:499-505

58. Soudham VP, Brandberg T, Mikkola JP, Larsson C (2014) Detoxification of acid pretreated spruce hydrolysates with ferrous sulfate and hydrogen peroxide improves enzymatic hydrolysis and fermentation. Bioresour Technol 66:559-565

\section{Submit your next manuscript to BioMed Central and take full advantage of:}

- Convenient online submission

- Thorough peer review

- No space constraints or color figure charges

- Immediate publication on acceptance

- Inclusion in PubMed, CAS, Scopus and Google Scholar

- Research which is freely available for redistribution

Submit your manuscript at

www.biomedcentral.com/submit
C Biomed Central 